\title{
Effect of Peppermint Water V/S Lanolin Ointment Application in Management of Cracked Nipple among Lactating Postnatal Women
}

\author{
Jisha K Jayan ${ }^{1}$, Santy John², Reshmi Siby ${ }^{3}$ \\ ${ }^{1}$ In charge Technician, AQH, Sharjah, ${ }^{2}$ Asst. Professor, Little Lourde, Kidangoor \\ ${ }^{3}$ Principal, BGHI College of Nursing, Indore \\ Corresponding Author: Jisha K Jayan
}

\begin{abstract}
Background of the study: Breast feeding is considered as the ideal method of feeding and nurturing infants. It is a dream for most mothers to have comfort in breast feeding, but sore nipples are still a common problem and pain or cracks frequently occur after breast feeding. The present study evaluated the Effect of peppermint water v/s lanolin ointment application in management of cracked nipple among lactating postnatal women.

Objectives: The objectives of the study were to assess the intensity of cracked nipple in lactating post-natal mothers, to compare the effect of Peppermint water and Lanolin in the management of cracked nipple, to find out the association between the pre interventional level of cracked nipples and selected demographic variables.

Methodology: The study design used was Quasi experimental two group pretest posttest design. Consecutive sampling was used to select 60 postnatal mothers with cracked nipple who met the sample selection criteria. Informed consent was obtained from the samples who fulfils the inclusion criteria. The tools used in this study were modified visual analogue scale, nipple soreness rating scale, nipple trauma scale. Out of 60 samples 30 were selected for Peppermint water application and 30 were selected for Lanolin ointment application.

Results: The data when analyzed using descriptive and inferential statistics revealed a significant reduction in the level of pain, soreness and trauma after the application of Peppermint water compared to lanolin ointment. There was no association between pre interventional level of cracked nipple and selected demographic variables.

Conclusion: The study concluded that Peppermint water is better than Lanolin ointment in management of cracked nipple among postnatal mothers. Cracked nipple is a prevalent problem among postnatal mothers and health care personnel should be equipped with good assessment tools and cost-effective interventions.
\end{abstract}

Key words: Peppermint water, Lanolin ointment, Cracked nipple, Lactating postnatal women

\section{INTRODUCTION}

Sore nipples associated with breast feeding are a common problem with an incidence ranging from $11 \%-96 \%$ and may lead to premature weaning ${ }^{1 .}$ This frequently occurs from suction trauma to the nipple secondary to incorrect positioning at the breast $^{2}$. Positioning of the baby's body is important for good attachment and successful breast feeding. An effective sucking technique is considered important to establish breast feeding, to ensure milk transfer and to prevent breast feeding problems $^{3}$

Cracked nipple is the loss of surface epithelium with the formation of raw area in the nipple or due to fissure either in the base or the tip of the nipple. It is estimated that 
$80-90 \%$ of breastfeeding women experience some nipple soreness, among these $26 \%$ progressing to cracks and extreme nipple pain ${ }^{4}$. Up to one third of the mothers who experience these symptoms may change to alternate methods for infant nutrition within six postnatal weeks.

The International Breastfeeding Survey Series (INBFS) in 2014 provides statistics on the obstacle of breast feeding. Most common reasons identified for stopping breast feeding are breast or nipple problems (51\%), not able to supply enough breast milk (47\%) and inability of baby to suck properly (29\%). ${ }^{5}$

An article published in Indian Journal of Public Health, 2015 showed the statistics that nearly $89 \%$ of the mother had one or more breast feeding problems. Major concern was difficulty in positioning and attaching the infant to the breast (88.5\%), followed by breast and nipple problems (30.3\%). Breast feeding problems continued to persist even after discharge in a significant proportion of the mothers (72.5\%). ${ }^{6}$

A double blinded randomized study was carried out in a sample of 216 postnatal women in Iran in 2010.The study aimed to compare the effect of Peppermint gel, Lanolin ointment and Placebo gel on the treatment of traumatic nipples. Participants were randomly divided in to 3 groups to receive one of 3 preparations. The study revealed that, nipple crack was less reported in mothers who received Peppermint gel (3.8\%) than in those who received Lanolin (11\%) and Placebo gel (22.6\%). The result showed that the formulated peppermint gel as a natural remedy and is effective in the prevention of nipple crack $^{1}$

A Quasi-experimental study was carried out in Behna city in 2012 to evaluate the effect of using pharmacological versus alternative therapy on traumatic nipple for lactating mothers. A comparison was done between Peppermint, Lanolin and Tea group. Purposive sampling technique was used to recruit 200 lactating mothers suffering from traumatic nipple. This study concluded that women using Peppermint for crack nipple had no pain and there was significant difference between the degrees of pain in samples. On the $7^{\text {th }}$ day (35\%) had no pain when compared with lanolin (22\%) and tea (16\%). Hence, Peppermint is found more effective than Lanolin and Tea ${ }^{2}$.

\section{Purpose}

The purpose of the study is to compare the effectiveness of Peppermint water v/s Lanolin ointment in management of cracked nipple.

\section{Objectives}

$>$ Assess the intensity of cracked nipple in lactating post natal mothers.

$>$ Compare the effect of Peppermint water and Lanolin in the management of cracked nipple.

$>$ Find the association between the pre interventional level of cracked nipples and selected demographic variables.

\section{Hypotheses}

- $\mathrm{H}_{1}$ - There will be significant difference between the effect of Peppermint and Lanolin application for cracked nipple.

- $\mathrm{H}_{2}$ - There will be an association between the pre interventional level of cracked nipples and selected demographic variables.

\section{MATERIALS AND METHODS}

Research approach: Quantitative approach Research design: Quasi experimental Two group pretest posttest design.

\section{Variables:}

- Independent variable - Peppermint water and Lanolin ointment application over the cracked nipples.

- Dependent variable- Intensity of cracked nipple.

Population: Lactating post-natal women

Sample and sampling technique: Sample consists of 60 lactating mothers who fulfil the sample selection criteria. 30 samples for Peppermint water application and remaining 30 for lanolin application. The sampling 
Jisha $K$ Jayan et.al. Effect of peppermint water v/s lanolin ointment application in management of cracked nipple among lactating postnatal women

technique used in this study was consecutive sampling.

\section{Criteria for sample selection: - Inclusion criteria:}

Lactating women

- in the first 2 weeks of post-natal period with cracked nipple.

- between the age group of 20-45 years

- willing to participate in the study

Exclusion criteria
Lactating women

- with breast feeding contraindicated

- who are intensively sick.

Tools

Description of tools

Tool 1: - Sample selection criteria: -The sample who meet at least 2 criteria will be selected for the study.

\section{Tool 2}

\section{Section A}

1. It consisted of socio demographic variables of patient including hospital number, date of delivery, gestational age, age in years, educational status, religion and family income.

Table 1

\begin{tabular}{|c|c|c|}
\hline S No. & Criteria & TICK MARK $(\sqrt{ })$ \\
\hline 1 & Redness & \\
\hline 2 & Pain & \\
\hline 3 & Tenderness & \\
\hline 4 & Nipple red and tender & \\
\hline 5 & Crack on the nipple & \\
\hline
\end{tabular}

\section{Section B}

The clinical data of the patients including, parity and mode of delivery.

The clinical data were filled by the investigator.

\section{Section C}

History of breast-feeding including number of feeds in 24 hours, condition of the nipple and length of a single feed.

Tool 3

Modified visual analogue scale

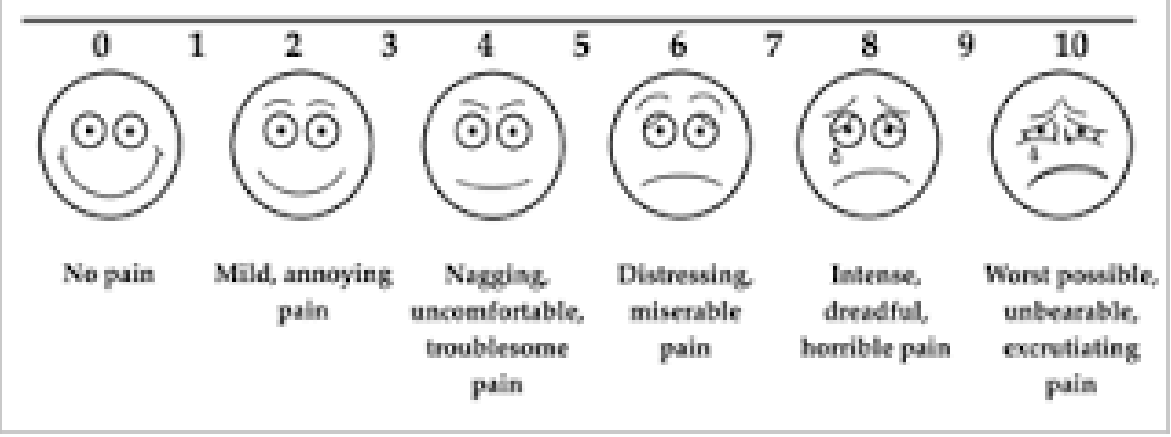

Table 2

\begin{tabular}{|c|c|c|c|}
\hline SCALE & NIPPLE-PAIN DESCRIPTION & SCORE & TICKMARK $(\sqrt{ })$ \\
\hline 0 & No pain & 0 & \\
\hline $1-2$ & Minor discomfort & 1 & \\
\hline $3-4$ & Moderate pain & 2 & \\
\hline $5-6$ & Severe pain & 3 & \\
\hline $7-8$ & Very Severe pain & 4 & \\
\hline 9-10 & The worst pain & 5 & \\
\hline
\end{tabular}

Table 3

Tool 4 Nipple Soreness Rating Scale

\begin{tabular}{|c|l|c|c|}
\hline Scale & \multicolumn{1}{|c|}{ Description of nipple soreness } & Score & TICK MARK( $\sqrt{ })$ \\
\hline 0 & Nipple color, no tenderness & 0 & \\
\hline 1 & Nipple slightly red and tender for first 5-10 seconds of feeding & 1 & \\
\hline 2 & Nipple red and tender for longer than first 5-10 seconds of feeding & 2 & \\
\hline 3 & Tender between feeding, make grimace when baby starts feeding & 3 & \\
\hline 4 & Nipple beginning to crack, involuntary gasp of pain when baby starts feeding & 4 & \\
\hline 5 & Nipple cracked, feels sore & 5 & \\
\hline
\end{tabular}

Nipple soreness rating scale to assess the soreness of nipple 
Jisha K Jayan et.al. Effect of peppermint water v/s lanolin ointment application in management of cracked nipple among lactating postnatal women

Tool 5

Table 4 Nipple Trauma Scale

\begin{tabular}{|c|c|c|c|}
\hline SCALE & DESCRIPTION OF NIPPLE TRAUMA & Score & TICK MARK $(\sqrt{ })$ \\
\hline 0 & No visible skin changes & 0 & \\
\hline 1 & Erythematic, edema or combination of both & 1 & \\
\hline 2 & Superficial damage with or without scar formation of less than $25 \%$ of the nipple surface & 2 & \\
\hline 3 & Superficial damage with or without scar formation of more than $25 \%$ of the nipple surface & 3 & \\
\hline 4 & Partial thickness wound with or without scar formation of less than $25 \%$ of the nipple surface & 4 & \\
\hline 5 & Partial thickness wound with or without scar formation of more than $25 \%$ of the nipple surface & 5 & \\
\hline
\end{tabular}

\section{Data analysis}

Descriptive statistics- Frequency and percentage distribution was used for representation of demographic variables and clinical data.

Inferential statistics- Independent $t$-test was used to compare the effectiveness of Peppermint water and lanolin ointment for cracked nipple among postnatal mothers.

Chi-square was used to find out the association between the pre interventional level of cracked nipple and selected socio demographic variables.

Ethical consideration: A written consent was obtained from the ethical review committee and concerned authority. Informed consent was obtained from the patients participating in the study. Confidentiality and anonymity of the subjects were maintained.

\section{RESULTS}

\section{Section A: Distribution of samples according to socio demographic variables.}

This section describes the sociodemographic data of samples studied such as age, education, religion and family income.
Table 5: Frequency and distribution of samples based on demographic variables (n-60)

\begin{tabular}{|l|c|c|}
\hline Demographic variables & Frequency (F) & Percentage (\%) \\
\hline Age in years & & 33.3 \\
\hline $20-25$ & 20 & 55 \\
\hline $26-30$ & 33 & 11.7 \\
\hline $31-35$ & 7 & 25 \\
\hline Education & & 55 \\
\hline Secondary & 15 & 20 \\
\hline Graduate & 33 & \\
\hline Post graduate & 12 & 45 \\
\hline Religion & & 50 \\
\hline Hindu & 27 & 5 \\
\hline Christian & 30 & \\
\hline Muslim & 3 & 11.7 \\
\hline Family income & & 41.7 \\
\hline Below 10000 & 7 & 46.7 \\
\hline $10000-20000$ & 25 & \\
\hline Above 20000 & 28 & \\
\hline
\end{tabular}

Table 6: Frequency and percentage distribution of pre intervention level of cracked nipple based on Clinical data $(\mathbf{n}=60)$

\begin{tabular}{|l|c|c|}
\hline \multicolumn{1}{|c|}{ Clinical Data } & Frequency (F) & Percentage (\%) \\
\hline Parity & & \\
\hline Primi & 39 & 65 \\
\hline Multi & 17 & 28.3 \\
\hline Grand multi & 4 & 6.7 \\
\hline Mode of delivery & & \\
\hline Normal & 25 & 41.7 \\
\hline Caesarean section & 33 & 55 \\
\hline Vacuum delivery & 2 & 33 \\
\hline Number of feeds & & \\
\hline $4-6$ & 5 & 41.7 \\
\hline $7-9$ & 25 & 50 \\
\hline $10-12$ & 30 & \\
\hline Condition of nipple & & 21.7 \\
\hline Erect & 25 & 30 \\
\hline Inverted & 17 & \\
\hline Flat & 18 & 13.3 \\
\hline Length of a single feed & & 53.3 \\
\hline $6-10$ & 8 & 33.3 \\
\hline $10-15$ & 32 & \\
\hline $16-20$ & 20 & \\
\hline
\end{tabular}

SECTION D - Pre and Post intervention level of cracked nipple among lactating postnatal mothers receiving both interventions.

Table 7: - Distribution of samples based on pain over the cracked nipple before and after the application of Peppermint water. Modified visual analogue scale (Group 1) $(\mathbf{n}=\mathbf{3 0})$

\begin{tabular}{|l|c|c|c|c|}
\hline Modified visual analogue scale & \multicolumn{2}{|c|}{ Pre interventional level } & \multicolumn{2}{c|}{ Post interventional level } \\
\hline & Frequency (f) & Percentage (\%) & Frequency(f) & Percentage (\%) \\
\hline No pain & 0 & 0 & 12 & 40 \\
\hline Minor discomfort & 0 & 0 & 14 & 46.6 \\
\hline Moderate pain & 12 & 40 & 4 & 13.3 \\
\hline Severe pain & 11 & 36.6 & 0 & 0 \\
\hline Very severe pain & 7 & 23.3 & 0 & 0 \\
\hline
\end{tabular}

Table 7 shows that $11(36.6 \%)$ of post-natal mothers had severe pain, $23.3 \%$ had very severe pain before the application of intervention and after the application of 
Jisha K Jayan et.al. Effect of peppermint water v/s lanolin ointment application in management of cracked nipple among lactating postnatal women

peppermint water $40 \%$ of sample had no pain and $46.6 \%$ had minor discomfort.

Table 8 shows that 7 (23.3\%) postnatal mothers had very severe pain and
33.3\% had severe pain before the application of lanolin ointment and after the application $53.3 \%$ had moderate pain and $20 \%$ had minor discomfort.

Table 8:- Distribution of samples based on pain over the cracked nipple before and after the application of Lanolin ointment. Modified visual analogue scale (Group 2) $(\mathbf{n}=30)$

\begin{tabular}{|l|c|c|c|c|}
\hline Description of MVAS & \multicolumn{2}{|c|}{ Pre interventional level } & \multicolumn{2}{c|}{ Post interventional level } \\
\hline & Frequency (f) & Percentage (\%) & Frequency $(\boldsymbol{f})$ & Percentage (\%) \\
\hline No pain & 0 & 0 & 6 & 20 \\
\hline Minor discomfort & 0 & 0 & 16 & 53.3 \\
\hline Moderate pain & 13 & 43.3 & 8 & 26.6 \\
\hline Severe pain & 10 & 33.3 & 0 & 0 \\
\hline Very severe pain & 7 & 23.3 & 0 & 0 \\
\hline
\end{tabular}

Table 9:- Distribution of samples based on soreness over the nipple before and after the application of Peppermint water. Nipple soreness rating scale (NSRS) Group 1 $(\mathbf{n}=30)$

\begin{tabular}{|c|c|c|c|c|}
\hline \multirow[t]{2}{*}{ Description of nipple soreness } & \multicolumn{2}{|c|}{ Pre interventional level } & \multicolumn{2}{|c|}{ Post interventional level } \\
\hline & $\begin{array}{l}\text { Frequency } \\
(f)\end{array}$ & $\begin{array}{l}\text { Percentage } \\
\text { (\%) }\end{array}$ & $\begin{array}{l}\text { Frequency } \\
(f)\end{array}$ & $\begin{array}{l}\text { Percentage } \\
(\%)\end{array}$ \\
\hline Nipple color, no tenderness & 0 & 0 & 10 & 33.3 \\
\hline Nipple slightly red and tender for first 5-10 seconds of feeding & 0 & 0 & 13 & 43.3 \\
\hline Nipple red and tender for longer than first 5-10 seconds of feeding & 0 & 0 & 7 & 23.3 \\
\hline Tender between feeding, make grimace when baby starts feeding & 5 & 16.6 & 0 & 0 \\
\hline $\begin{array}{l}\text { Nipple beginning to crack, involuntary gasp of pain when baby } \\
\text { starts feeding }\end{array}$ & 12 & 40 & 0 & 0 \\
\hline Nipple cracked, feels sore & 13 & 43.3 & 0 & 0 \\
\hline
\end{tabular}

Table 10:- Distribution of samples based on soreness over the nipple before and after the application of Lanolin ointment. Nipple soreness rating scale (NSRS) (Group 2)

\begin{tabular}{|c|c|c|c|c|}
\hline \multirow[t]{2}{*}{ Description of nipple soreness } & \multicolumn{2}{|c|}{ Pre interventional level } & \multicolumn{2}{|c|}{ Post interventional level } \\
\hline & $\begin{array}{l}\text { Frequency } \\
(f)\end{array}$ & $\begin{array}{l}\text { Percentage } \\
(\%)\end{array}$ & $\begin{array}{l}\text { Frequency } \\
(f)\end{array}$ & $\begin{array}{c}\text { Percentage } \\
(\%)\end{array}$ \\
\hline Nipple color, no tenderness & 0 & 0 & 0 & 0 \\
\hline Nipple slightly red and tender for first 5-10 seconds of feeding & 0 & 0 & 13 & 43.3 \\
\hline Nipple red and tender for longer than first 5-10 seconds of feeding & 0 & 0 & 6 & 20 \\
\hline Tender between feeding, make grimace when baby starts feeding & 6 & 20 & 10 & 33.3 \\
\hline $\begin{array}{l}\text { Nipple beginning to crack, involuntary gasp of pain when baby } \\
\text { starts feeding }\end{array}$ & 14 & 46.6 & 8 & 26.6 \\
\hline Nipple cracked, feels sore & 10 & 33.3 & 6 & 20 \\
\hline
\end{tabular}

Table 11:- Distribution of samples based on trauma over the nipple before and after the application of Peppermint water. Nipple trauma scale (NTS) Group 1

\begin{tabular}{|c|c|c|c|c|}
\hline \multicolumn{5}{|c|}{ Nipple trauma scale (NTS) Group $1 \quad$ (n=30) } \\
\hline \multirow{2}{*}{ Description of nipple trauma } & \multicolumn{2}{|c|}{ Pre interventional level } & \multicolumn{2}{|c|}{ Post interventional level } \\
\hline & $\begin{array}{l}\text { Frequency } \\
(f)\end{array}$ & $\begin{array}{l}\text { Percentage } \\
(\%)\end{array}$ & $\begin{array}{l}\text { Frequency } \\
(f)\end{array}$ & $\begin{array}{l}\text { Percentage } \\
(\%)\end{array}$ \\
\hline No visible skin changes & 0 & 0 & 10 & 33.3 \\
\hline Erythematic, edema or combination of both & 0 & 0 & 12 & 40 \\
\hline $\begin{array}{l}\text { Superficial damage with or without scar formation of less than } 25 \% \text { of } \\
\text { the nipple surface }\end{array}$ & 13 & 43.3 & 8 & 26.6 \\
\hline $\begin{array}{l}\text { Superficial damage with or without scar formation of more than } \\
25 \% \text { of the nipple surface }\end{array}$ & 14 & 46.6 & 0 & 0 \\
\hline $\begin{array}{l}\text { Partial thickness wound with or without scar formation of less than } \\
25 \% \text { of the nipple surface }\end{array}$ & 3 & 10 & 0 & 0 \\
\hline $\begin{array}{l}\text { Partial thickness wound with or without scar formation of more than } \\
25 \% \text { of the nipple surface }\end{array}$ & 0 & 0 & 0 & 0 \\
\hline
\end{tabular}

Table 9 shows that 13(43.3\%) nipples cracked and feel sore before the application of peppermint and after the application 10(33.3\%) had no redness and tenderness,13(43.3\%) had slight redness and tenderness for $1^{\text {st }} 5-10$ sec of feeding.

Table 10 shows that $10(33.3 \%)$ had cracked nipple, $46.6 \%$ had nipple begin to crack before the application of Lanolin ointment and after the intervention 6(20\%) had cracked nipple and26.6\% had nipple begin to crack.

Table 11 shows that $13(43.3 \%)$ of samples had partial thickness wound before the application of peppermint water and after the application of intervention 33.3\% have no visible skin changes and 12(40\%) have only erythema or edema. 
Jisha $K$ Jayan et.al. Effect of peppermint water v/s lanolin ointment application in management of cracked nipple among lactating postnatal women

Table 12 shows that $5(16.6 \%)$ had partial thickness wound and $43.3 \%$ had partial thickness wound without scar formation of less than $25 \%$ before the application of Lanolin and after the intervention 5 (16.6\%) had erythema or edema only and $43.3 \%$ had only superficial damage and $6.6 \%$ had partial thickness wound without scar formation.

Table 12:- Distribution of samples based on trauma over the nipple before and after the application of Lanolin ointment. Nipple trauma scale (NTS)Group 2

$(\mathbf{n}=\mathbf{3 0})$

\begin{tabular}{|c|c|c|c|c|}
\hline \multirow{2}{*}{ Description of nipple trauma } & \multicolumn{2}{|c|}{ Pre interventional level } & \multicolumn{2}{|c|}{ Post interventional level } \\
\hline & $\begin{array}{l}\text { Frequency } \\
(f)\end{array}$ & $\begin{array}{c}\text { Percentage } \\
(\%)\end{array}$ & $\begin{array}{l}\text { Frequency } \\
(f)\end{array}$ & $\begin{array}{l}\text { Percentage } \\
(\%)\end{array}$ \\
\hline No visible skin changes & 0 & 0 & 0 & 0 \\
\hline Erythematic, edema or combination of both & 0 & 0 & 5 & 16.6 \\
\hline $\begin{array}{l}\text { Superficial damage with or without scar formation of less than } 25 \% \text { of } \\
\text { the nipple surface }\end{array}$ & 0 & 0 & 13 & 43.3 \\
\hline $\begin{array}{l}\text { Superficial damage with or without scar formation of more than } \\
25 \% \text { of the nipple surface }\end{array}$ & 12 & 40 & 10 & 33.3 \\
\hline $\begin{array}{l}\text { Partial thickness wound with or without scar formation of less than } \\
25 \% \text { of the nipple surface }\end{array}$ & 13 & 43.3 & 0 & 0 \\
\hline $\begin{array}{l}\text { Partial thickness wound with or without scar formation of more than } \\
25 \% \text { of the nipple surface }\end{array}$ & 5 & 16.6 & 2 & 6.6 \\
\hline
\end{tabular}

Section E: - The effect of Peppermint water application v/s Lanolin ointment for cracked nipple among lactating postnatal women.

Table 13:- Mean, SD, Mean Difference and t-value in pretest and post test level of pain in both groups. (n= 60)

\begin{tabular}{|c|c|c|c|c|c|}
\hline \multirow{2}{*}{$\begin{array}{l}\text { Group } \\
\text { MVAS }\end{array}$} & Mean & SD & MD & t value & table value \\
\hline & & & & & \\
\hline \begin{tabular}{ll}
\multicolumn{2}{l}{ Pre test } \\
- & Group 1 \\
- & Group 2
\end{tabular} & $\begin{array}{l}2.83 \\
2.80\end{array}$ & $\begin{array}{l}.791 \\
.805\end{array}$ & .003 & .162 & \\
\hline \begin{tabular}{ll}
\multicolumn{2}{l}{ Post test } \\
- & Group 1 \\
- & Group 2
\end{tabular} & $\begin{array}{c}.73 \\
2.07\end{array}$ & $\begin{array}{l}.691 \\
.691\end{array}$ & -1.333 & 7.468 & 2.04 \\
\hline
\end{tabular}

Table 13 shows that there was a significant difference in the mean of group 1 and II (.73 and 2.07). The student $t$ test calculated value was 7.468 with 58 df. But at $5 \%$ significance level the table value of $t$
$=2.04$. Since the calculated value is greater than the table value it is concluded that the degree of pain in group 1 was reduced significantly when compared to lanolin ointment.

Table 14:- Mean, SD, Mean Difference and t-value in pretest and posttest level of soreness in both groups. (n = 60)

\begin{tabular}{|c|c|c|c|c|c|}
\hline Group & Mean & SD & MD value & t value & table value \\
\hline NSRS & & & & & \\
\hline Pretest & $\begin{array}{l}4.27 \\
4.13\end{array}$ & $\begin{array}{l}.740 \\
730\end{array}$ & 133. & .703 & \\
\hline $\begin{array}{ll}\text { - } & \text { Group } 2 \\
\text { Post test } \\
\text { - } & \text { Group } 1 \\
\text { - } & \text { Group } 2\end{array}$ & $\begin{array}{c}4.13 \\
90 \\
2.93\end{array}$ & $\begin{array}{r}.759 \\
1.507\end{array}$ & -2.33 & 6.60 & 2.04 \\
\hline
\end{tabular}

Table 14 reveals that the mean value of group 1 and II was (.90 and 2.93). The student $t$ test calculated value was 6.60 with $58 \mathrm{df}$. But at 5\% significance level the table value of $t=2.04$. Since the calculated value is greater than the table value it concluded that in group 1 the soreness level decreased more when compared to group II.
Table 15 reveals that the mean score in group 1 and II were (.93 and 2.3) Student t test calculated value was 6.525 with 58 df. But at $5 \%$ significance level the table value of $t=2.04$. Since the calculated value is greater than the table values it concluded that the level of trauma reduced more in Peppermint group than lanolin.

Hence the research hypothesis $\mathrm{H}_{1}$ is accepted. 
Jisha $K$ Jayan et.al. Effect of peppermint water v/s lanolin ointment application in management of cracked nipple among lactating postnatal women

Table 15:- Mean,SD, Mean Difference and t-value in pretest and post test level of trauma in both groups.

\begin{tabular}{|l|l|l|l|l|l|}
\hline \multicolumn{1}{|c|}{ Group } & Mean & SD & MD value & t value & table \\
\hline NTS & & & & & \\
\hline $\begin{array}{l}\text { Pretest } \\
\text { • Group 1 }\end{array}$ & 2.67 & .661 & -1.00 & 5.57 & \\
$\bullet \quad$ Group 2 & 2.77 & .728 & & & \\
$\begin{array}{l}\text { Post test } \\
\text { - Group 1 }\end{array}$ & .93 & .785 & & & \\
$-\quad$ Group 2 & 2.3 & .837 & -1.367 & & \\
\hline
\end{tabular}

Table 16

SECTION F: - Association between pre interventional level of cracked nipple and selected demographic variables in relation to MVAS. $(\mathbf{n}=\mathbf{6 0})$

\begin{tabular}{|c|c|c|c|c|c|}
\hline $\begin{array}{c}\text { Demographic } \\
\text { Variables }\end{array}$ & $\begin{array}{c}\text { Moderate } \\
\text { pain }\end{array}$ & Severe pain & $\begin{array}{l}\text { Very severe } \\
\text { pain }\end{array}$ & $\overline{\text { df }}$ & $\chi^{2}$ \\
\hline \multicolumn{6}{|l|}{ Age } \\
\hline $20-25$ & 10 & 7 & 3 & \multirow[t]{3}{*}{4} & \multirow[t]{3}{*}{1.556} \\
\hline $26-30$ & 12 & 12 & 9 & & \\
\hline $31-35$ & 3 & 2 & 2 & & \\
\hline \multicolumn{6}{|l|}{ Education } \\
\hline Secondary & 4 & 7 & 4 & \multirow[t]{4}{*}{4} & \multirow[t]{3}{*}{5.183} \\
\hline Graduate & 18 & 96 & & & \\
\hline Post graduate & 3 & 54 & & & \\
\hline \multicolumn{5}{|l|}{ Family income } & \\
\hline Below 10000 & 4 & 21 & 4 & \multirow[t]{3}{*}{6} & \multirow[t]{3}{*}{2.122} \\
\hline $10000-20000$ & 11 & 77 & & & \\
\hline Above 20000 & 10 & 12 & & & \\
\hline
\end{tabular}

Table 16 shows that the calculated value of Chi square is less than the table value 9.49 with df 4 for all the variables selected for association on basis of MVAS. Therefore, there is no significant association between pre interventional level of cracked nipple and demographic variables such as age, education and monthly income. Hence the research hypothesis $\mathrm{H}_{2}$ is rejected.

Table 17

SECTION F: - Association between pre interventional level of cracked nipple and selected demographic variables based in relation to NSRS

\begin{tabular}{|l|c|c|c|c|c|}
\hline $\begin{array}{c}\text { Demographic } \\
\text { Variables }\end{array}$ & $\begin{array}{c}\text { Tender between } \\
\text { feeding }\end{array}$ & $\begin{array}{c}\text { nipple begin to } \\
\text { crack }\end{array}$ & nipple cracked & df & $\chi^{2}$ \\
\hline Age & & & & & \\
\hline $20-25$ & 4 & 10 & 6 & & \\
\hline $26-30$ & 6 & 12 & 15 & 4 & 1.949 \\
\hline $31-35$ & 1 & 4 & 2 & & \\
\hline Education & & & & & \\
\hline Secondary & 3 & 5 & 7 & & \\
\hline Graduate & 7 & 18 & 8 & 4 & 7.555 \\
\hline Post graduate & 1 & 3 & 8 & & \\
\hline Family income & & & & & \\
\hline Below 10000 & 2 & 3 & 2 & & \\
\hline 10000-20000 & 4 & 11 & 10 & 4 & .681 \\
\hline Above 20000 & 5 & 12 & 11 & & \\
\hline
\end{tabular}

Table 17 shows that the calculated value of Chi square is less than the table value 9.49 with df 4 for all the variables selected for association on basis of NSRS. Therefore, there is no significant association between pre interventional level of cracked nipple and demographic variables such as age, education and monthly income. Hence the research hypothesis $\mathrm{H}_{2}$ is rejected.
Table 18 shows that the calculated value of Chi square is less than the table value 9.49 with df 4 for all the variables selected for association in relation to NTS. Therefore, there is no significant association between pre interventional level of cracked nipple and demographic variables such as age, education and monthly income. Hence the research hypothesis $\mathrm{H}_{2}$ is rejected. 
Jisha K Jayan et.al. Effect of peppermint water v/s lanolin ointment application in management of cracked nipple among lactating postnatal women

Table 18

SECTION F: - Association between pre interventional level of cracked nipple and selected demographic variables based in relation to NSRS (n-60)

\begin{tabular}{|c|c|c|c|c|c|}
\hline $\begin{array}{l}\text { Demographic } \\
\text { Variables }\end{array}$ & $\begin{array}{l}\text { Superficial } \\
\text { damage }<25 \%\end{array}$ & $\begin{array}{l}\text { Superficial } \\
\text { damage }>25 \%\end{array}$ & $\begin{array}{l}\text { Partial thickness } \\
\text { wound }\end{array}$ & df & $\chi^{2}$ \\
\hline \multicolumn{6}{|l|}{ Age } \\
\hline $20-25$ & 10 & 7 & 3 & \multirow{3}{*}{4} & \multirow{3}{*}{23.78} \\
\hline $26-30$ & 12 & 16 & 5 & & \\
\hline $31-35$ & 3 & 4 & 0 & & \\
\hline \multicolumn{6}{|l|}{ Education } \\
\hline Secondary & 4 & 8 & 3 & \multirow{3}{*}{4} & \multirow{3}{*}{6.166} \\
\hline Graduate & 18 & 11 & 4 & & \\
\hline Post graduate & 3 & 8 & 1 & & \\
\hline \multicolumn{6}{|l|}{ Family income } \\
\hline Below 10000 & 4 & 3 & 0 & \multirow{3}{*}{4} & \multirow{3}{*}{2.669} \\
\hline $10000-20000$ & 10 & 10 & 5 & & \\
\hline Above 20000 & 11 & 14 & 3 & & \\
\hline
\end{tabular}

\section{DISCUSSION}

The present study assessed the effect of peppermint water $\mathrm{v} / \mathrm{s}$ lanolin ointment application in management of cracked nipple among lactating postnatal women in maternity wards. The objectives were to assess the intensity of cracked nipple in lactating post-natal mothers, to compare the effect of Peppermint water and Lanolin in the management of cracked nipple, to find out the association between the pre interventional level of cracked nipples and selected demographic variables. The study was conducted using quasi experimental design. The conceptual framework used was based on goal attainment theory for nursing developed by Imogene M King (1981).

The investigator selected 60 samples by non-probability consecutive sampling technique. During the pre-interventional level, the investigator assessed the level of pain, soreness and trauma of cracked nipple by using 3 different tools. Alternate samples were allotted to group 1 (peppermint water) and group 2 (lanolin ointment), this process was carried out until both groups had 30 samples each. Out of 60 samples, 30 were selected for Peppermint water application and 30 for lanolin ointment. Both interventions were applied 6 times a day. Application was continued for 4 days and assessed the final level of cracked nipple using the same tools. During the posttest the mean of Peppermint group (MVAS-.73, NSRS -0.90 and NTS-0.93 was less than the mean of lanolin group (MVAS-2.07, NSRS2.93, NTS-2.3). Using the independent samples t- test it was found that there was a significant difference in the mean intensity of pain, soreness and trauma score. The calculated value of independent $t$ test is (7.468, 6.60and 6.5250) for MVAS, NSRS and NTS respectively which is greater than the table value (2.04). It was inferred that there was a significant reduction in the degree of pain, soreness and trauma of cracked nipple with the application of peppermint water compared to lanolin ointment application.

These findings are supported by a randomized trial of peppermint gel, lanolin ointment, and placebo gel to prevent nipple crack in primiparous breastfeeding women conducted in 2007 at Iran. Two hundred and sixteen primiparous participants were assigned randomly to three groups. Each group applied only one of the above three preparations on both breasts for 14 days. On the $6^{\text {th }}$ week rate of nipple and areola crack and pain was evaluated. Nipple crack were less in mothers who received peppermint gel than in those who received lanolin ointment or placebo $\left(\mathrm{c}^{2}=16.8, \mathrm{df}=6, \mathrm{P}=0.01\right)$. Relative risk of nipple crack in the lanolin group (RR: 2.41, 95\%CI: 1.20-3.01) was higher than in the peppermint group (RR: 1.85, 95\%CI: 1.64-3.10). The study concluded that peppermint gel application is more effective than lanolin and placebo. ${ }^{1}$

The association between the pre interventional level of cracked nipple with selected demographic variables was calculated by Chi square $\left(\chi^{2}\right)$ and it shows that there was no association between pre 
Jisha $K$ Jayan et.al. Effect of peppermint water v/s lanolin ointment application in management of cracked nipple among lactating postnatal women

interventional level of cracked nipple and selected demographic variables. The findings of the present study were analyzed and discussed with the findings of other similar studies. This helped the investigator to prove that findings were true and the intervention was cost effective in reducing the level cracked nipple.

Result proved that both peppermint and lanolin ointment were cost effective interventions in reducing cracked nipple. It was well appreciated and accepted by subjects.

\section{Limitation}

- Mothers are reluctant to participate in the study because of lack of awareness about the intervention.

- Some mothers were not bothered about their cracked nipple.

- The sample size was limited to 60 samples only.

\section{Recommendation}

- Similar study can be replicated on a large sample for better generalization.

- A study can be conducted to assess the effectiveness of peppermint on prevention of cracked nipple.

- Another study can be conducted to assess the perception of the postnatal mothers regarding the use of peppermint.

- Another study can be conducted to evaluate the effect of other natural measures such as honey, olive oil and breast milk on cracked nipple.

\section{Compliance with ethical standard}

Obtained permission from Institutional ethical committee before conducting the study Informed consent was obtained from samples.
Conflicts of interest: There is no conflict of interest among the authors.

Acknowledgement: None

Source of Funding: None

\section{REFERENCES}

1. HaA, Manal A, Samira A, Amer Alsaif. Prevention of nipple crack with peppermint versus breast milk in lactating primiparous women. Jeddah. Life science journal: 2013;10(4)

2. Soad, Abd-Elsalam, ShadiaHamiodo, Howyida. Effect of using pharmacological versus alternative therapy on traumatic nipples for lactating mothers.Egpt. Journal of American science ;2011;7(11):485-96.

3. ManizhehSayyahMelli,Mohmmad Rezza Rashidi,Ali,SiminTagavi,LayaFarzadi,Zoreh et al. A randomized trial of peppermint gel ,lanolin,and placebo gel to prevent nipple crack in primiparous breast feeding women.Iran. International Breast feeding Journal;2007;13(9):406-410.

4. Dutta DC, Text book of obstetrics, $6^{\text {th }}$ ed. New Delhi: Central publication; 190-98.

5. ZiemerMM, Paone JP, Schupay J, Cole E. Methods to prevent and manage nipple pain in breastfeeding women. Midwifery women health ;7(4) 732-43.

6. Tait $P$, Nipple pain in breastfeeding women: causes, treatment, and prevention strategies. Midwifery Women's Health: 2010;45 (3): 212-5.

How to cite this article: Jayan JK, John S, Siby R. Effect of peppermint water $\mathrm{v} / \mathrm{s}$ lanolin ointment application in management of cracked nipple among lactating postnatal women. Int $J$ Health Sci Res. 2021; 11(12):70-78. DOI: https://doi.org/10.52403/ijhsr.20211211 